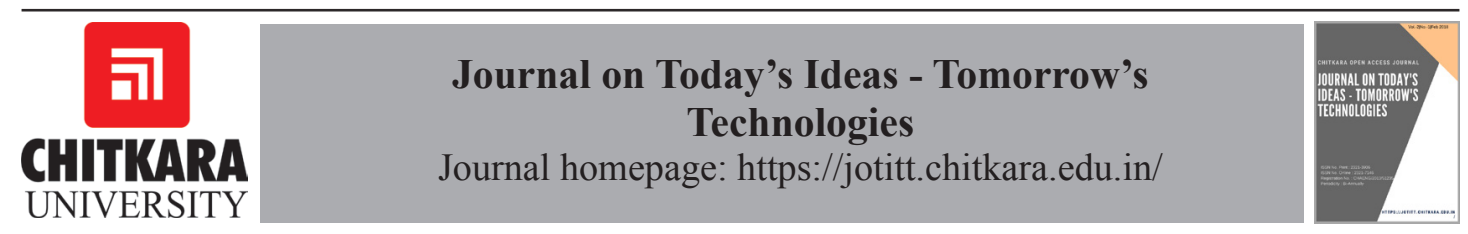

\title{
Pedestrian Safety on Crosswalks in India - Need of the Hour
}

\author{
Ankit Bansal ${ }^{1}$, Tripta Goyal ${ }^{2}$, Umesh Sharma ${ }^{3}$ \\ Civil Engineering Department, Punjab Engineering College, Chandigarh, India.

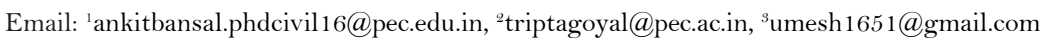

ARTICLE INFORMATION

DOI: $10.15415 /$ jotitt.2018.61004

Keywords: Crosswalks, Pedestrian

Facilities, Level of Safety,

Performance

\begin{abstract}
A paradigm shift has been observed from 'moving of vehicles' to 'moving of persons' while planning for transportation facilities in cities. Provision of integrated and barrier free pedestrian facilities is essential to ensure inclusive mobility. Pedestrian facilities are a critical component in producing a pedestrianfriendly environment. In India, the present facilities provided for the pedestrians are not efficient in general and crosswalks (zebra crossings) in particular. The pedestrian casualties in India have registered an increase of 11.7 percent in the year 2017, of which 31 percent have occurred on crosswalks. Therefore, an attempt has been made to overview the level of safety provided on the crosswalks. It has been found that majority of crosswalks are not fulfilling their intended purposes due to improper signage and markings, inadequate maintenance and bad surface condition. Another significant reason hampering the safety of pedestrians at crosswalks has been found to be inappropriate provision of guardrails and pedestrian refuge islands. Hence, some measures have been suggested to augment the pedestrian safety on the crosswalks.
\end{abstract}

\section{Introduction}

Every traveller is a pedestrian at some stage of his or her travel. Every trip begins and ends on foot. Nowadays, developed countries have made a massive development by making the cities, pedestrian and bicyclist friendly to motivate the citizens to walk or use cycle for short trips. Walking has become an important mode of transportation that provides a better environment due to reduced pollution. In order to encourage the use of non-motorised methods of transportation, designers and planners have to provide with a structure which is more suitable for road users and minimise conflicts with the vehicular traffic. Several agencies and organisations like the World Health Organisation, World Bank, etc. have stressed that the number of road deaths are more in the developing countries. Road Traffic Injuries (RTI) and fatalities have become a major hindrance

\footnotetext{
The Author(s) 2018. This article is published with open access at www.chitkara.edu.in/publications. https://doi org//10.15415/ jotitt.2018.61004 | ISSN No.: 2321-3906 (Print) ISSN No.: 2321-7146 (Online) Registration No. : CHAENG/2013/51235
} Periodicity: Bi-Annually 
to global economic growth and utterly influence safety and quality of life of road users across the globe [1]. Among all road users, pedestrians are more susceptible to road accidents and majority of these accidents take place at crosswalks provided either at intersections or mid-block road segments.

Crosswalks are an integral part of the road network provided for the use of pedestrians to cross the road safely in the presence of vehicular traffic. Marked pedestrian crossings are frequently found at intersections and on busy roads that would otherwise be too apprehensive to cross. These are usually installed where large numbers of walkers attempt to cross (for instance in shopping areas) or where vulnerable road users (for instance school children) regularly cross. The signalised and un-signalised crosswalks (pedestrian crossings) separate pedestrians and the road vehicles. Despite that, most of the pedestrian fatalities are recorded while crossing the street. This is due to larger waiting times or improper design of the crosswalks [2-3]. Therefore, there is a need to analyse the safety measures provided at the crosswalks.

\section{Pedestrian accidents}

\subsection{Global scenario}

Road traffic injuries has been found to occur more often in the developing nations than the developed nations. The Global Status Report on Road Safety 2015, indicates that among the 180 countries, the total number of road traffic deaths have plateaued at 1.25 million per year. Also, it was stated that the highest road traffic fatality rates were observed in low-income countries. Low and Middle-Income countries (LMICs) approximately accounts for more than 85 percent of all deaths from road traffic injuries worldwide. The average rate was found to be 17.4 per 100,000 people. In low-income countries, annual road traffic fatality rate was highest at 24.1 per 100,000, whereas rate in highincome countries was lowest at 9.2 per 100,000. In addition, over a one-third of road traffic deaths in low- and middle-income countries were among pedestrians and cyclists [4].

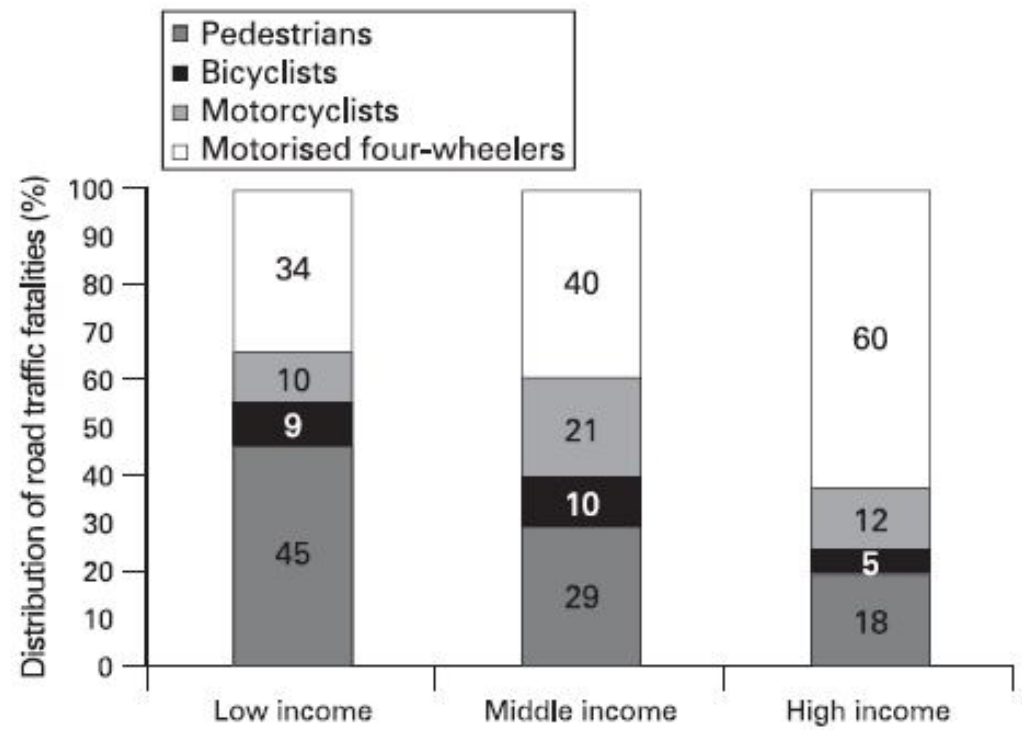

Figure 1: Distribution of road traffic deaths among different countries [Source: Naci et al., 2009] 
Fig. 1 depicted that in low-income countries on an average 45 percent of road traffic death rate was observed among pedestrians, 29 percent in middle-income countries and 18 percent in high-income countries [5]. By the year 2016, the Global Burden of Disease project report estimated that on an average, pedestrians still accounted for 40 percent of traffic deaths in Low and Middle-Income Countries (LMICs) and 39 percent globally [6].

\subsection{Indian scenario}

Similarly, in India, the present rate of pedestrian fatalities is about 10.5 percent which is less than the neighbouring countries (Bangladesh: 34 percent, China: 26 percent, Pakistan: 35 percent, Sri Lanka: 32 percent) [7]. According to official statistics, 150,785 persons were killed and 494,624 were injured in road traffic crashes in India in year 2016 indicating an increase of 3 percent in road crash fatalities (from 1,46,133 in 2015 to $1,50,785$ in 2016). Accident severity also increased by 2.3 percent (from 29.1 in 2015 to 31.4 in 2016) [8]. However, these statistics are probably undervalued as most of the accidents are not reported to the authorities [9-10]. It was also observed that the total number of road crash deaths increased by 31 percent from 2007 to 2017 and that of fatal road crashes increased by 25.6 percent in the same period. Moreover, it was seen that 15, 746 pedestrians were killed in road crashes contributing to a share of $10.5 \%$ in total road crash deaths in 2016, as against 13, 894 in 2015 . This suggests that there has been a spike in pedestrian deaths by $11.7 \%$ in the last one year. It was noted that, of all the pedestrian road accident deaths, about 60 percent of accidents were recorded in urban areas with 85 percent occurring at crosswalks [11-12]. This indicates high pedestrian-vehicle conflicts at the crosswalk locations. However, the significant reduction of about 30 percent in number of deaths was seen in large cities (with population greater than 5 million) i.e. Bengaluru, Chennai, Delhi, Hyderabad and Mumbai. Increase in traffic congestion in such cities has forcibly reduced the vehicular speed, thus, decreased the overall rate of accidents. Despite the reduction in total deaths, the total number of deaths of susceptible road users (pedestrians, bicyclists, and motorised two-wheeler riders) in these five cities still range between 84-93 percent [13]. The key risks to pedestrians are related to a broad range of factors including driver behaviour particularly in terms of speed, drink and drive; lack of infrastructure in terms of dedicated facilities for pedestrians such as sidewalks, raised crosswalks and medians. Therefore, it is essential to mitigate the risks and provide various facilities to enhance the safety of pedestrians.

\section{Previous studies related to pedestrian safety in India}

In India, every year numerous pedestrians die or get brutally injured in traffic accidents. The large number of accidents occur in urban areas because of constant interaction between vehicles and pedestrians and this interaction is maximum at the time of crossing. This can be observed from the previous studies undertaken in the past in India, which are presented in Table 1 with their key findings and suggestions. 
Table 1: Literature review of studies related to pedestrian safety in India

\begin{tabular}{|c|c|c|}
\hline Author & Key Findings & Suggestions (if any) \\
\hline $\begin{array}{l}\text { Najamuddin } \\
\text { and Parida, } \\
2004[14]\end{array}$ & $\begin{array}{l}\text { - Pedestrians were found to be the main } \\
\text { prey of fatal accidents. } \\
\text { Nearly } 90 \text { percent of the total fatali- } \\
\text { ties in our country occurred on rural/ } \\
\text { village roads whereas } 10 \text { percent were } \\
\text { observed on roads in urban areas. }\end{array}$ & $\begin{array}{l}\text { Pedestrian safety needs to in- } \\
\text { corporate a unified structure } \\
\text { of roads, road users and ve- } \\
\text { hicular traffic. }\end{array}$ \\
\hline $\begin{array}{l}\text { Kumar and } \\
\text { Kulkarni, } \\
2010[15]\end{array}$ & $\begin{array}{l}\text { - More than } 20 \text { percent of the road acci- } \\
\text { dents involved pedestrians. } \\
\text { For the past } 10 \text { years, } 8 \text { percent growth } \\
\text { has been observed in road traffic fatal- } \\
\text { ities with about } 60 \text { percent pedestrian } \\
\text { fatalities of all fatalities occurring in } \\
\text { urban areas. }\end{array}$ & $\begin{array}{l}\text { Transport professionals } \\
\text { should also focus on pedestri- } \\
\text { an safety to make city safer. }\end{array}$ \\
\hline $\begin{array}{l}\text { Mohan et al., } \\
2011[16]\end{array}$ & $\begin{array}{l}\text { - Overall and road user specific fatality } \\
\text { rates did not have a high relationship } \\
\text { with country income levels. }\end{array}$ & $\begin{array}{l}\text { More Reliable data needs to } \\
\text { be collected. }\end{array}$ \\
\hline $\begin{array}{l}\text { Sharma et al., } \\
2013[17]\end{array}$ & $\begin{array}{l}\text { - Access density, Shoulder width and } \\
\text { Lane width found to have significant } \\
\text { impact on pedestrian safety. }\end{array}$ & -- \\
\hline $\begin{array}{l}\text { Rankavat } \\
\text { and Tiwari, } \\
2013[18]\end{array}$ & $\begin{array}{l}\text { - An estimated } 8503 \text { fatalities in road } \\
\text { traffic crashes were recorded in Delhi } \\
\text { from 2006-2009, with } 51 \text { percent of pe- } \\
\text { destrians' deaths. } \\
\text { - It was also revealed that the pedestrian } \\
\text { fatalities at arterial road intersections in } \\
\text { Delhi involving cars and buses were } 27 \\
\text { percent and } 14 \text { percent respectively. }\end{array}$ & --- \\
\hline $\begin{array}{l}\text { Vignesh- } \\
\text { kumar and } \\
\text { Vijay, } 2014 \\
{[19]}\end{array}$ & $\begin{array}{l}\text { - The methodology for evaluating road } \\
\text { safety management was accessed and } \\
\text { road network improvement techniques } \\
\text { are proposed. } \\
\text { The safety awareness and training to } \\
\text { the public was given. The education, } \\
\text { enforcement and the emergency care of } \\
\text { the people was trained under this study. } \\
\text { Many people affected from major acci- } \\
\text { dents were reported and recorded for } \\
\text { improving the road safety in India. }\end{array}$ & -- \\
\hline
\end{tabular}

ISSN No.: 232 1-3906 (Print) ISSN No.: 232 1-7146 (Online) Registration No.: CHAENG/2013/51235 Periodicity: Bi-Annually 
Table 1: Literature review of studies related to pedestrian safety in India (Continued)

\begin{tabular}{|c|c|c|}
\hline Author & Key Findings & Suggestions (if any) \\
\hline 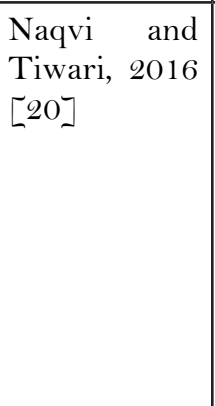 & $\begin{array}{l}\text { - The study results showed that six-lane } \\
\text { NH had four times higher fatal crashes } \\
\text { per km per year than two-lane NH. } \\
\text { - It was also revealed that probability } \\
\text { of occurrence of such fatal pedestrian } \\
\text { crashes were twice on four-lane NH and } \\
\text { approximately one and half times on } \\
\text { six-lane NH as compared to two-lane } \\
\text { NH. }\end{array}$ & $\begin{array}{l}\text { Pedestrian facilities combined } \\
\text { with speed calming at pedes- } \\
\text { trian crash prone location(s) } \\
\text { on undivided as well as di- } \\
\text { vided highways are to be in- } \\
\text { corporated in design for two- } \\
\text { lane highways and at the time } \\
\text { of upgradation of two-lane } \\
\text { highways to four-lane or six- } \\
\text { lane highways }\end{array}$ \\
\hline $\begin{array}{l}\text { Rankavat } \\
\text { and Tiwari, } \\
2016[21]\end{array}$ & $\begin{array}{l}\text { - Zebra Crossings were more preferred by } \\
\text { pedestrians because the perception about } \\
\text { its convenience level was high as com- } \\
\text { pared to other simple crossings. This } \\
\text { reflected that pedestrians gave higher } \\
\text { priority to convenience than safety. } \\
\text { - Female pedestrians did not use underpass- } \\
\text { es and zebra-crossings that frequently. } \\
\text { Age had a negative correlation with the us- } \\
\text { age of overpasses as it decreased with age. }\end{array}$ & \\
\hline $\begin{array}{l}\text { Dass et al., } \\
2017[22]\end{array}$ & $\begin{array}{l}\text { - The most critical factors responsible for } \\
\text { pedestrian safety were found out by do- } \\
\text { ing an extensive literature survey and } \\
\text { also methods were devised which would } \\
\text { provide solution for the same. }\end{array}$ & --- \\
\hline $\begin{array}{l}\text { Moran et al., } \\
2017[23]\end{array}$ & $\begin{array}{l}\text { - A strong correlation existed between } \\
\text { Euro New Car Assessment Program } \\
\text { (NCAP) pedestrian scores and real-life } \\
\text { pedestrian injuries. } \\
\text { In Europe, considerable reductions in } \\
\text { pedestrian injuries were noted due to im- } \\
\text { proved car front end design. But the sim- } \\
\text { ilar measure could not be adopted for the } \\
\text { United States. This would give the max- } \\
\text { imum benefit in low- and middle-income } \\
\text { countries like India that have a greater } \\
\text { percentage of pedestrian road crashes. }\end{array}$ & - \\
\hline
\end{tabular}


Table 1: Literature review of studies related to pedestrian safety in India (Continued)

\begin{tabular}{|c|c|c|}
\hline Author & Key Findings & Suggestions (if any) \\
\hline $\begin{array}{l}\text { Kumar et al., } \\
2018[24]\end{array}$ & $\begin{array}{l}\text { - } 22.6 \text { percent of pedestrians observed } \\
\text { performed a distracting activity while } \\
\text { crossing. } \\
\text { Most of the pedestrians crossed the } \\
\text { road by hesitating ( } 32.1 \text { percent) and by } \\
\text { running ( } 28.2 \text { percent). } \\
\text { Pedestrians with technological and so- } \\
\text { cial distractions were more prone for } \\
\text { road traffic injuries }\left(\chi^{2}=31.59, \mathrm{df}=4 \text {, }\right. \\
\mathrm{p}=0.001) \text {. }\end{array}$ & $\begin{array}{l}\text { There is a need to implement } \\
\text { pedestrian safety rules and to } \\
\text { provide facilities for pedestri- } \\
\text { ans in the infrastructure of } \\
\text { roads in India and effective } \\
\text { interventions to protect pe- } \\
\text { destrians. }\end{array}$ \\
\hline $\begin{array}{l}\text { Shah and Ve- } \\
\text { dagiri, } 2018 \\
{[25]}\end{array}$ & $\begin{array}{l}\text { - The effect of vehicle type and the ve- } \\
\text { hicle approaching speed on the severity } \\
\text { of the conflict under non-lane-based } \\
\text { mix traffic condition was described. } \\
\text { - Additionally, Post Encroachment Time } \\
\text { (PET) values were also set for high- } \\
\text { ly severe conflict, severe conflict, and } \\
\text { normal conflict which could be used for } \\
\text { the prediction of the severity of the } \\
\text { conflict at unsignalized intersections in } \\
\text { India. }\end{array}$ & --- \\
\hline
\end{tabular}

From the literature, it is observed that pedestrian's interaction with trucks, tractors, buses and cars, three/two-wheelers, etc., is highly unavoidable due to mixed traffic scenario in India and the major issue is the level of safety on the crosswalks. The probable reasons observed for more number of accidents at crosswalks are improper signage and markings, inadequate maintenance and bad surface condition. Therefore, safety policies in India must focus on issues concerning safety of Vulnerable Road Users (VRUs), especially pedestrians.

\section{Initiatives for pedestrian safety in India}

A number of engineering solutions to improve the quality of the pedestrian network should take into account all groups: children, families with young children, elderly persons, persons with disabilities, and people carrying heavy luggage. This concept has more significance in urban areas where the density of people as well as vehicle is quite high and conflicts of pedestrian and vehicles are frequent. The situation has even worsened due to lack of skilful drivers with a little traffic education, using relatively less advanced roadways and enforcement systems. Developed nations such as the United States, Canada, Australia, and those in Europe have made progress in pedestrian safety in recent years. India has also begun addressing pedestrian's safety needs to a larger extent. Several initiatives have been undertaken in some 
metropolitan cities to allow free movement of pedestrians which will also ensure their safety [26].

a) Bengaluru-tender sure: Under this scheme, the streets are made more pedestrian friendly and additional amenities are provided to the road- users (e.g. pedestrian friendly island) as shown in Fig. 2. Moreover, the roads in the IT hub will have 50 card-enabled public bicycle sharing points, 35 e-toilets and 420 smart dustbins with sensors that will encourage more and more users to switch to non-motorized modes.

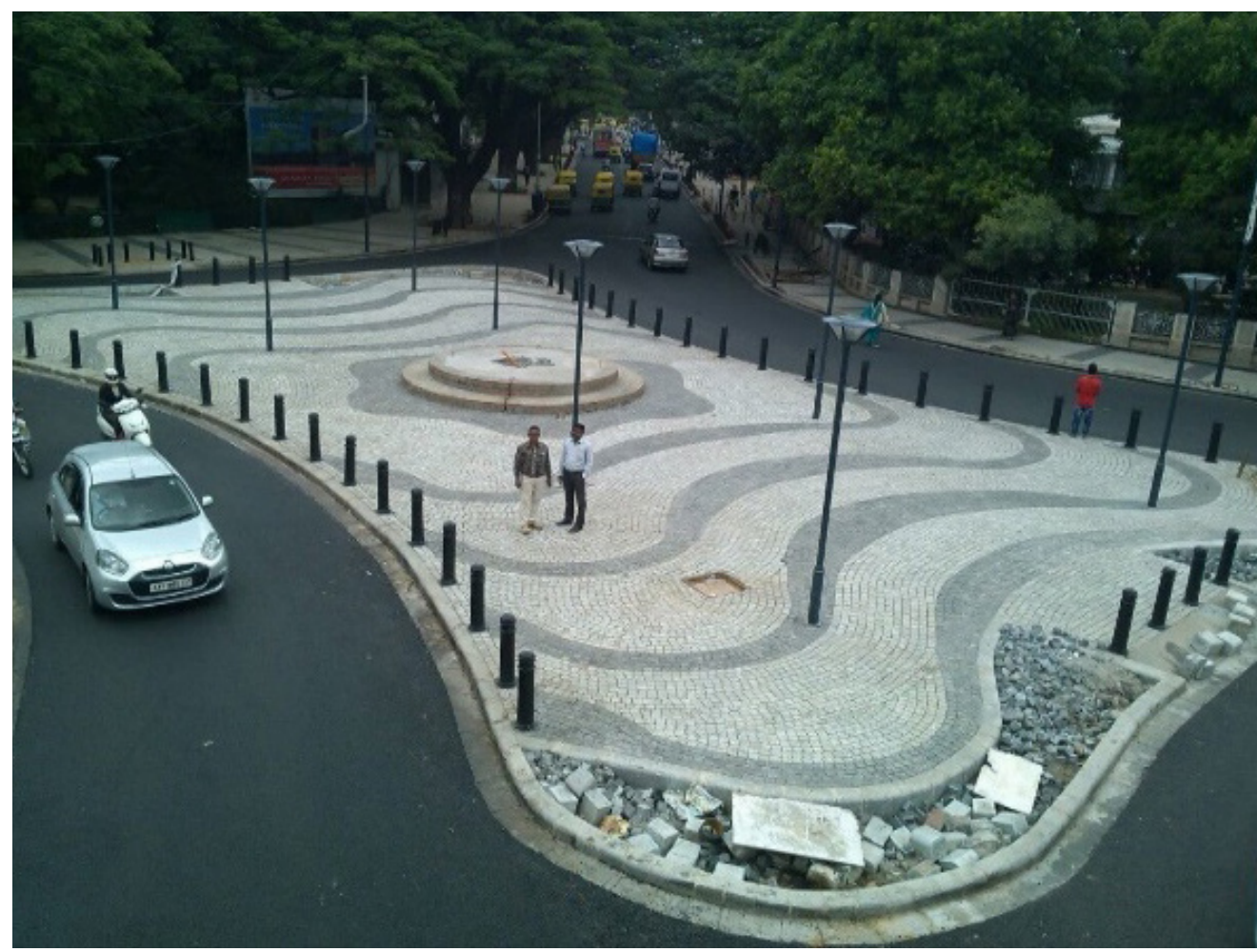

Figure 2: A pedestrian friendly island on St. Mark's road, Bangalore [27]

b) Chennai- prioritises pedestrians: Chennai prioritises pedestrians by planning to increase the share of pedestrians and cyclists on its roads by 40 percent by the end of year 2018 . Footpaths will be provided along 80 percent of the roads (as shown in Fig.
3) for ensuring the safety of pedestrians and for encouraging more walking and will enhance the beauty of city. The 2-metre wide roads will have spaces for shops as well as enough spaces for landscaping and street art. 


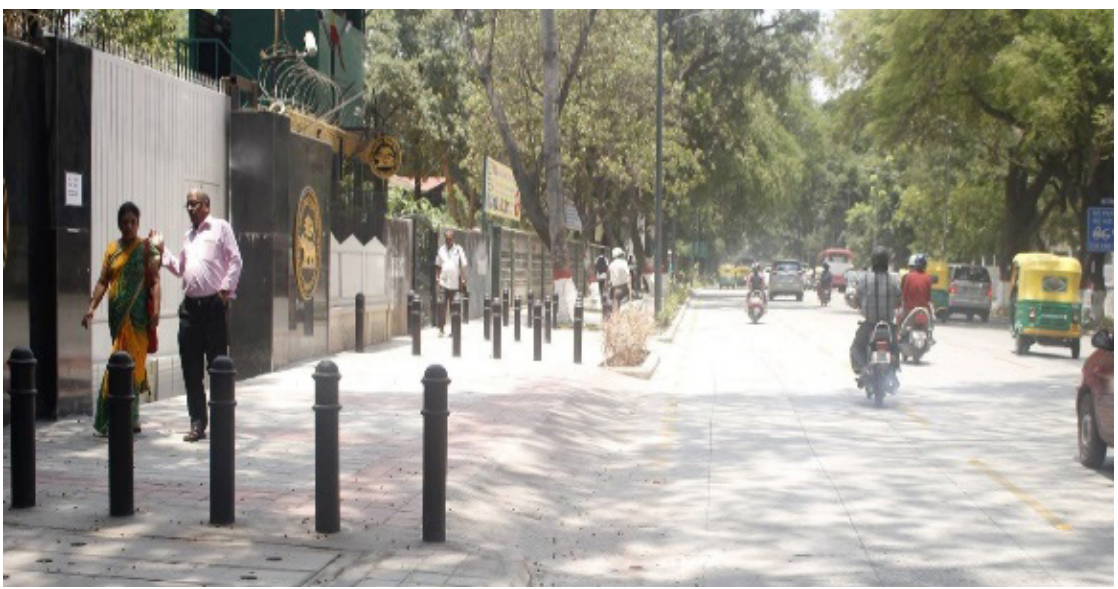

Figure 3: A wide footpath for pedestrians to walk freely, Chennai [28]

c) Hyderabad-pedestrian refuge islands.

The refugee islands (2-3-m wide and $0.3 \mathrm{~m}$ tall) provided in Hyderabad are constructed in the middle of closed crossroads as shown in Fig. 4. The islands. These islands are different from the normal medians because they divide vehicular traffic as well as provide safety to the pedestrians who are crossing the road. However, these islands make sure that pedestrians cross only from the designated areas of the road since they provide a halting space to pedestrians.

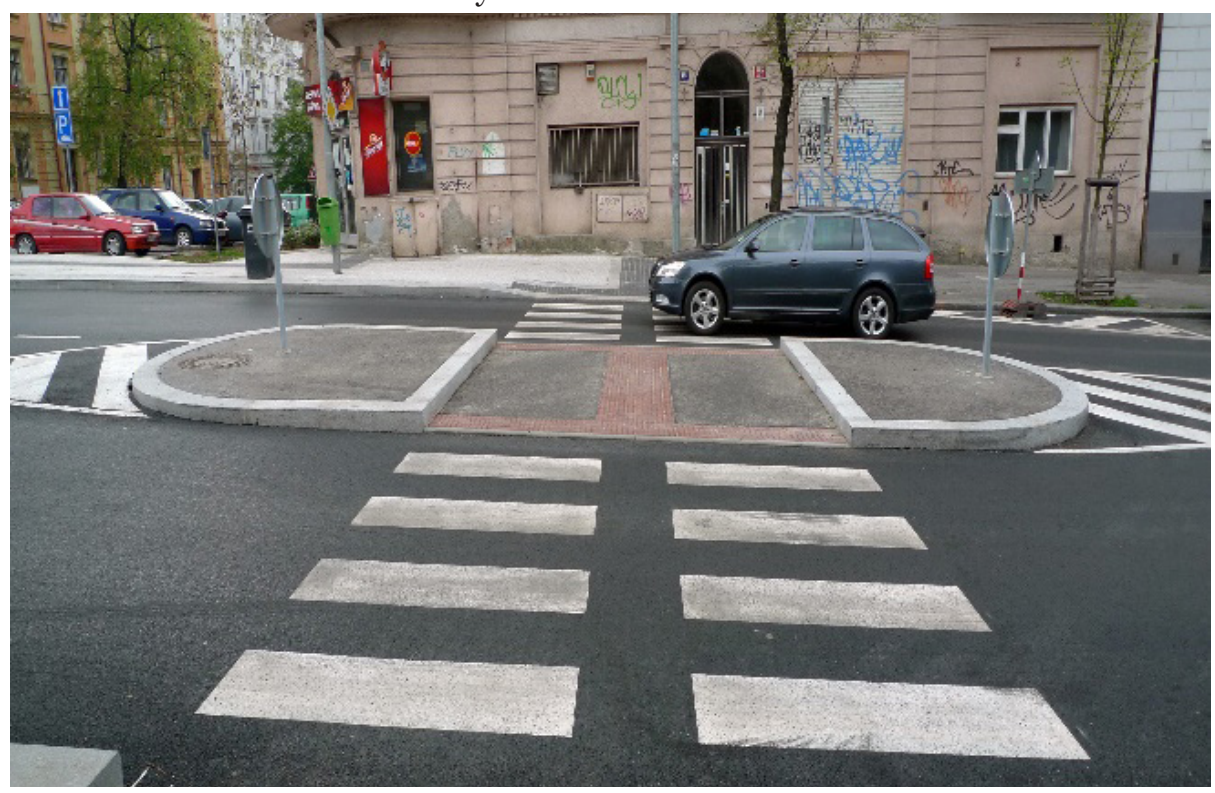

Figure 4: A representative image of a pedestrian refuge island, Hyderabad [29] 
d) Chandigarh-Pelican signals: Pelican signals provided in Chandigarh City (shown in Fig. 5) are another great way to direct pedestrian traffic to a designated point to cross a street. Pedestrians can
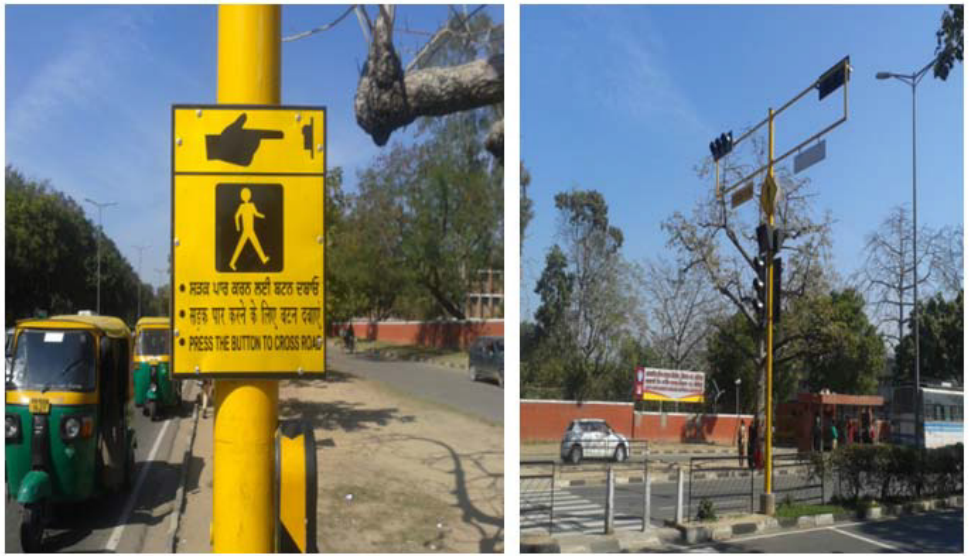

Figure 5: Installed PELICAN Signal at Madhya Marg in Chandigarh [30]

e) Hyderabad-3D paintings: A $3 \mathrm{D}$ cartoon (as shown in Fig. 6) is painted on several of junctions of Hyderabad city to make the drivers more aware of their push a button on pelican signals which flashes a red sign to the vehicles at appropriate times, thus enabling them to safely cross the road [30].

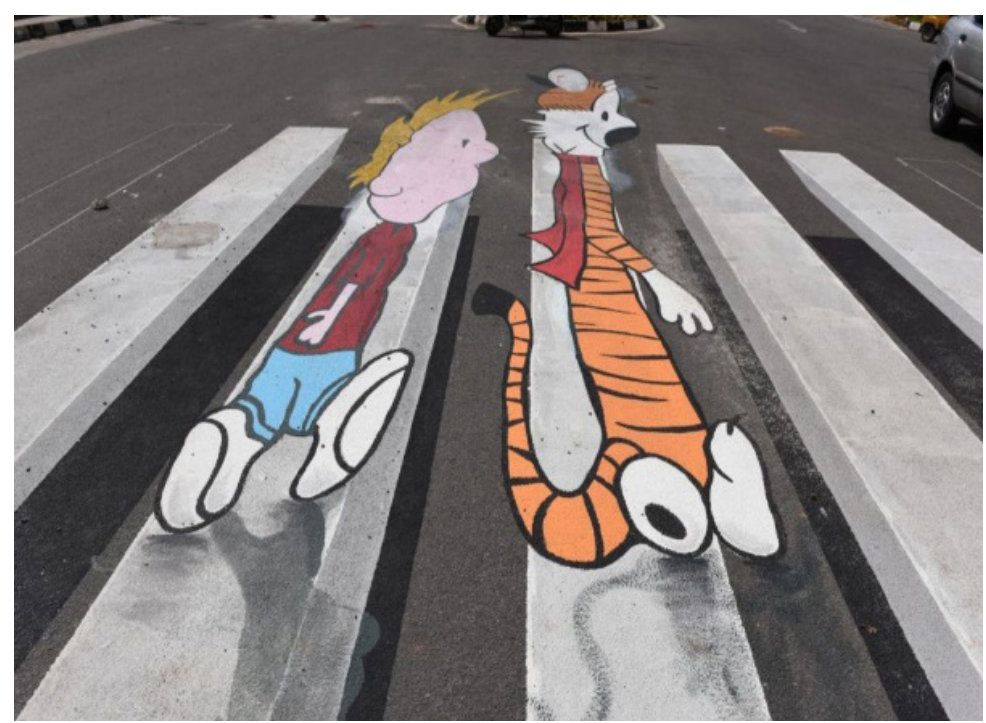

Figure 6: A 3D crossing, Hyderabad [31]

ISSN No.: 232 1-3906 (Print) ISSN No.: 232 1-7146 (Online) Registration No.: CHAENG/2013/51235 Periodicity: Bi-Annually 
f) Endorsing car-free streets: Under this, the roads are completely closed for the vehicular traffic and get a pleasant makeover with recreational events and activities promoting pedestrian safety like Zumba classes, slacklining, casual talent shows and band performance as depicted

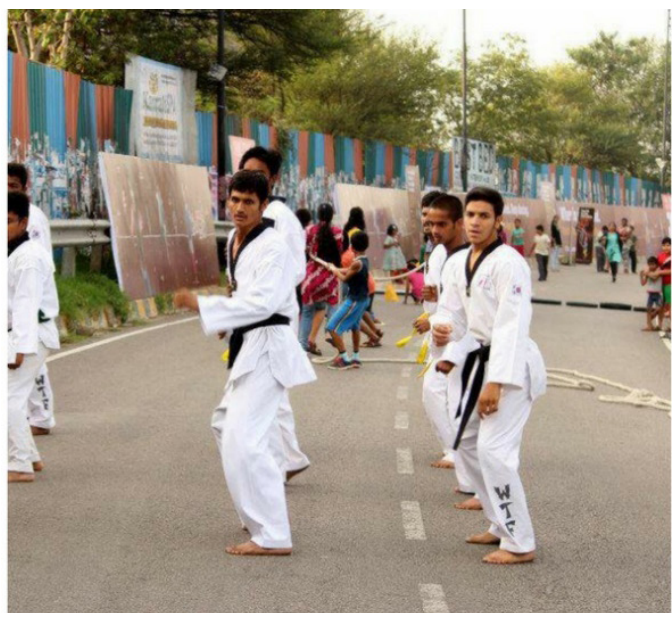

in Fig. 7, being organised on the road itself. A total of 56 cities in India, including Gurgaon, Delhi, Mumbai, Thane, and Pune have organised car-free streets on selected days and made people aware of the benefits of using non-motorised modes through various activities.

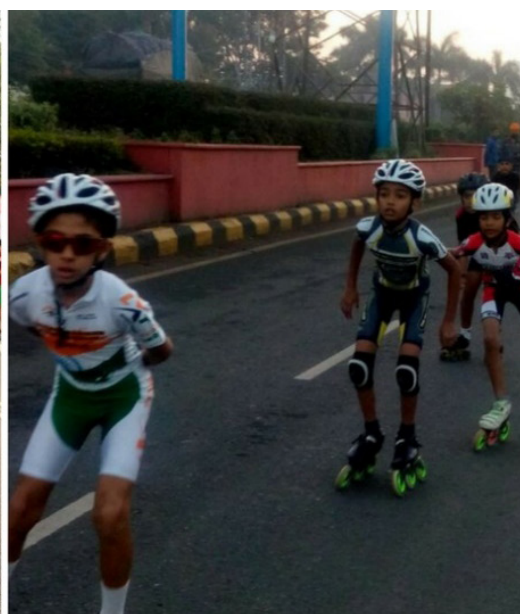

Figure 7: Roads get a makeover on car-free days [32]

\section{Conclusions}

Crosswalks are vital links in a city's pedestrian network. They provide a right-ofway for pedestrians and separate them from vehicular traffic to reduce conflicts. However, these crosswalks are the critical locations with maximum number of pedestrian fatal accidents. Low and Middle-Income Countries recorded over one-third road traffic deaths of pedestrians and cyclists. The similar trend was observed in India which highlighted that the Indian roads are not safer for pedestrians. The pedestrian deaths in road accidents were found to be 37 percent of all the fatalities. Majority of these accidents took place at crosswalks in urban areas because of the constant interaction between vehicles and pedestrian. Therefore, there is a need to incorporate the safety measures like provision of proper countdown timer signals at the crosswalks which will help pedestrians to make effective crossing decisions. It is also recommended to provide 3D crosswalks which will facilitate the motorised traffic to slow down and give right of way to pedestrians, thereby improving the pedestrian safety.

\section{References}

[1] WHO (World Health Organization) and World Bank., World Report on Road Traffic Injury Prevention Summary, World Health Organisation and World Bank, Geneva, Switzerland, pp. 3-164, 2014.

[2] G. Tiwari, S. Bangdiwala, A. Saraswat and S. Gaurav, "Survival analysis: Pedestrian risk exposure at signalized intersections", Transportation Research Part F: Traffic Psychology and Behavior, vol. 10, no. 2, pp. 77-89, 2007. 
[3] B. R. Kadali and P. Vedagiri, "Review of pedestrian level of service: perspective in developing countries", Transportation Research Record: Journal of the Transportation Research Board, vol. 2581, pp. 37-47, 2016.

[4] WHO (World Health Organization) "Global Status Report on Road Safety", World Health Organisation, Geneva, Switzerland, 2015.

[5] H. Naci, D. Chisholm and T. D. Baker, "Distribution of road traffic deaths by road user group: A global comparison”, Injury Prevention, vol. 15, pp. 1-15, 2009.

[6] J. A. Haagsma, Graetz and I. Bolliger, "The global burden of injury: Incidence, mortality, disability-adjusted life years and time trends from the global burden of disease study 2013", Injury Prevention, vol. 22, pp. 3-18, 2016.

[7] WHO (World Health Organization) "Global Burden Disease Estimates Report”, World Health Organisation, Geneva, Switzerland, 2015.

[8] PRS Legislative Research "Overview of Road Accidents in India”, New Delhi, India, pp. 1-3, 2017.

[9] D. Mohan, O. Tsimhoni, M. Sivak and M. J. Flannagan, "Road safety in India: challenges and opportunities", University of Michigan Transport Research Institute, Ann Arbor, Michigan, pp. 1-57, 2009.

[10] K. Bhalla et al. "Official government statistics of road traffic deaths in India under-represent pedestrians and motorised two-wheeler riders", Injury Prevention, pp. 1-7, 2016.

[11] MoRTH (Ministry of Road Transport and Highways) "Road crash statistics", Transport research wing, New Delhi, India, 2017.

[12] NCRB (National Crime Records Bureau), Traffic Accidents. Accidental Deaths and
Suicides in India”, Ministry of Home Affairs, New Delhi, India, 2017.

[13] D. Mohan, G. Tiwari and K. Bhalla, "Road safety in India: status report", Transportation Research and Injury Prevention Programme (TRIPP), New Delhi, India, pp. 1-64, 2016.

[14] S. Najamuddin and P. Parida, "Development of measures for pedestrian safety on indian roads", Institute of Town Planning India, 4, pp. 43-46, 2004.

[15] P. Kumar, S. Y. Kulkarni and M. Parida, Pedestrian Safety in Multi Modal Public Transport: A Way Forward to Create Safer City , IIT Roorkee, India, pp. 1-9, 2010 .

[16] D. Mohan, "Analysis of road traffic fatality data for asia", Journal of the Eastern Asia Society for Transportation Studies, vol. 9, pp. 1786-1794, 2011.

[17] A. K. Sharma, V. S. Landge and N. V. Deshpandem, "Modelling motorcycle accident on rural highway", International Journal of Chemical, Environmental \& Biological Sciences (IJCEBS), vol. 1, no. 2, pp. 313-317, 2013.

[18] S. Rankavat and G. Tiwari, "Pedestrian accident analysis in delhi using GIS", Journal of the Eastern Asia Society for Transportation Studies, vol. 10, pp. 14461457, 2013.

[19] K. Vigneshkumar and P. Vijay, "Study on road safety improvement in India", International Journal of Research in Engineering and Technology, vol. 3, no. 11, pp. 198-201, 2014.

[20] H. M. Naqvi and G. Tiwari, "Risk factors for fatal pedestrian crashes on national highways in India", Transportation Research Board 95th Annual Meeting, pp. 4612, 2016.

[21] S. Rankavat and G. Tiwari, "Pedestrians perceptions for utilization of pedestrian 
facilities - delhi, India", Transportation Research Part F: Traffic Psychology and Behavior, vol. 42, no. 3, pp. 495-499, 2016.

[22] S. Dass, P. Aggarwal and D. Singhal, "Pedestrian safety on indian roads - A review of recent studies", International Journal of Engineering Technology Science and Research, vol. 4, no. 9, pp. 955-967, 2017.

[23] D. Moran, D. Bose and K. Bhalla, "Impact of improving vehicle crashworthiness design on the burden of injuries to pedestrians in USA, Germany and India”, Traffic Injury Prevention, vol. 18, no. 8, pp. 832-838, 2017.

[24] Kumar, N.P., Nandini, C., Saranya, R. and Sridevi, N. H. "Impact of pedestrian crossing behavior at intersections on road traffic accidents in shivamogga", Karnataka: an observational study", International Journal of Community Medicine and Public Health, vol. 5, no. 6, 2018.

[25] H. Shah and P. Vedagiri, "Proactive Pedestrian safety evaluation at unsignalized intersections in India using surrogate safety measures", Transportation Research Board 97 $7^{\text {th }}$ Annual Meeting, Washington DC, United States, 2018.

[26] T. Patel, “5 Pedestrian-Friendly Measures All of India Should Adopt to Keep Us Safe", Retrieved from The Better India, [Online] Available: https://www. thebetterindia.com/127110/pedestrian-friendly-india-safe/, 2018 [Accessed: July 20 2018].

[27] Google Images, "A pedestrian friendly island on St. Mark's road, Bangalore. [Online], Available: https://www. google.co.in/A+pedestrian+friendly+island+on+St.+Mar/, [Accessed: July 20, 2018].

[28] Google Images, " $A$ wide footpath for pedestrians to walk freely", Chennai. [Online]
, Available: https://www.google.co.in/ A+wide+footpath+to+walk+freely/, [Accessed: July 20, 2018]..

[29] Google Images, "A representative image of a pedestrian refuge island, Hyderabad. [Online], Available: https://www. google.co.in/A+representative $+i m-$ age + of $+\mathrm{a}+$ pedestrian+refuge+island/, [Accessed: July 20, 2018].

[30] U. Sharma and A. Anand, "Installation of Pedestrian Pelican Signals on Indian Roads - State of the Art”, Journal of Civil Engineering and Environmental Technology, vol. 2, no. 4, pp. 354-357, 2015.

[31] Google Images, “A 3-D Crossing”, Hyderabad. [Online], Available: https://www. google.co.in/A+3-D+crossing/, [Accessed: July 20, 2018]..

[32] Google Images, "Roads get a makeover on Car-Free Days", [Online], Available: https://www.google.co.in/ Roads + get $+\mathrm{a}+$ makeover+on + Car+Free+Days/, [Accessed: July 20, 2018].

ISSN No.: 2321-3906 (Print) ISSN No.: 2321-7146 (Online) Registration No.: CHAENG/2013/51235 Periodicity: Bi-Annually 